undertaking. The eompleted survey of the placenames of the whole of Yorkshire will carry our knowledge of the evolution of the life and landscape of England a most important stage forward. At a different level of comprehension and enjoyment, it is pleasant to turn over the pages and see the rich and curious variety that characterizes English placenames. Parish names such as Cridling Stubbs, Purston Jaglin and Thorpe Salvin cannot fail to excite our euriosity. These three volumes are not only for scholarly reference but also for delightful browsing.

H. C. Darby

\section{SCIENTIFIC ATTITUDE TO MANAGEMENT}

Management Sciences, Models and Techniques

Proceedings of the Sixth International Meeting of the Institute of Management Seiences, Paris, 7-11 September, 1959. Edited by Prof. C. West and Prof. Michel Verhulst. Vol. 1: Pp. xxix +602 . Vol. 2 : Pp. xiv +511. (London and New York: Pergamon Press, 1960.) 200s. net per set.

STABLISHED six years ago, the Institute of 1. Management Sciences has made much more progress than even its enthusiastic founder members had cause to hope for. This is reflected in the Proceedings of the Sixth International Meeting, which was held in Paris during September 7-11, 1959, and which run to a weighty two volumes of concentrated report.

The meeting was supported by about a thousand participants from all parts of the world. Not unexpectedly, many of those attending came from the United States, and, again not unexpectedly in view of Britain's relative backwardness in management education, there were comparatively few British representatives. At present it would appear that other European countries and countries in the Commonwealth are showing greater interest in the scientific approach to problems of management than is the case in Britain.

Six years ago the complexity of management problems made it doubtful whether the scientist could make a noticeable contribution over a short period of time. During those six years the number of scientific personnel entering the management field has increased significantly, and there has been a corresponding if, as yet, limited advance along a number of sectors. Techniques like simulation, linear programming and the theory of decisionmaking have been applied to management tasks, sometimes with success verging on the phenomenal. Attention has also been paid to problem areas in production and inventory control, as well as to the place and performance of research and development departments.

These and related topics were all considered at the Paris meeting. Prof. Myron Gordon, of the Massachusetts Institute of Technology, showed that even the optimum amount of profit which a business should distribute can be analytically determined. Contributions from Norway and the Argentine gave examples of how little-developed industrial countries are using tools like operations research to stimulate their economies. From Britain, Prof. R. W. Revans presented a case-study to show how our hospital services need scientific help in their management, while F. de P. Hanika, now of Churchill College, Cambridge, presented a thoughtful paper describing the role of management sciences in training and education for management; his shrewd admixture of theory and practice should appeal to managing directors and teachers of management subjects in university or technical college.

Of the papers presented, however, a large proportion was directed to the area of business games. During the past few years there has been rapid progress in the development of analytical descriptions of entire business enterprises. These games are proving increasingly useful in management training as well as for research in investigating group interactions in industry and commerce; participants were able to sample games which had been developed and played in the United States, France, Denmark and Great Britain, and Management Sciences, Models and Techniques contains detailed descriptions of the game as well as comments from the players.

The two volumes make a noteworthy contribution to the application of science in management thinking and, by inference, indicate how ill-equipped many practising managers are to meet the challenge of the next decade. The need for a good basic education with more than a modicum of mathematics shines like a beacon on every page of this not inconsiderable book. So does the need for management scientists to eschew that extrapolative jargon which is already threatening to choke clear thinking and make them intelligible only to one another.

For such an important work the book is unevenly produced. Although intended for English-speaking readers, many outstanding American contributions are presented only as the briefest of abstracts; quite a number of contributions in French are set out in expansive detail, including the extraneous. It would appear that, for speed and economy, conference papers issued to participants have been printed by a number of different firms; when brought together to form a substantial book the effect is patchy and does not make for easy reading. Full contributions in one language with abstracts in the other might lead to the desired economies and produce more satisfying proceedings.

T. H. HAWKINS

\section{TROPICAL FLORAS IN THE TERTIARY IN SOUTHERN ENGLAND}

The Lower Tertiary Floras of Southern England. I. Palaeocene Floras ; London Clay Flora (Supplement). By Marjorie Elizabeth Jane Chandler. Pp. xi $+354+$ Atlas of 34 plates. (London: British Museum (Natural History), 1961.) 200s. net.

LARGE part of this book is a supplement to The London Clay Flora by Mrs. Clement Reid and Miss Chandler, published by the British Museum (Natural History) in 1933. In this joint work they gave a description fully illustrated with photographic reproductions of the fossil plants, mostly fruits and seeds, found in the London Clay, which is part of the Early Eocene of the south of England. They devised special methods of investigating the internal structure of these fossils, which are partially lignitized and partially pyritized and uncompressed. A great deal of information about their histology could be obtained and enabled close comparisons to be made with the corresponding organs of existing natural 